\title{
Aluminum Inhibits Vitellogenin Production via Toxic Effects on Hepatocytes in the Rockfish Sebastes schlegelii
}

\author{
Un-Ki Hwang*, Han-Seung Kang, Yoon Lee and Jae-Kyoung Shon \\ Fisheries Resources and Environment Division, West Sea Fisheries Research Institute (WSFRI), Incheon 400-420, Korea
}

\begin{abstract}
Effects of aluminum (Al) on plasma vitellogenin (VTG), alkaline-labile phosphorus (ALPP), calcium (Ca), glutamate pyruvate transaminase (GPT), the hepatosomatic index (HSI), and hepatic Al concentration were examined in estradiol-17 $\beta$ ( $\left.\mathrm{E}_{2}\right)$-administered immature rockfish Sebastes schlegeli. Fish were injected intraperitoneally with $\mathrm{E}_{2}(5 \mathrm{mg} / \mathrm{kg}$ body weight [BW]) and/or Al (0, $0.1,1,5$, and $10 \mathrm{mg} / \mathrm{kg} \mathrm{BW}$ ) and plasma and liver samples were extracted 7 days later. After sodium dodecyl sulfate polyacrylamide gel electrophoresis, the relative amount of VTG was determined by integrated optical density. VTG accounted for $23.6 \%$ of the total proteins in the control group, but this value decreased with increasing Al administration. Al reduced the concentrations of $\mathrm{ALPP}$ and $\mathrm{Ca}$ in a concentration-dependent manner and significant reduction occurred at $\mathrm{Al}$ concentrations greater than $5 \mathrm{mg} / \mathrm{kg}$. The concentration of GPT increased in a concentration-dependent manner in all Al-administered rockfish. The concentrations of $\mathrm{Al}$ in the liver also increased, and HSI was decreased, in a concentration-dependent manner. These results suggest that Al inhibits $\mathrm{E}_{2}$-induced VTG production by being toxic to hepatocytes in marine fish.
\end{abstract}

Key words: Aluminum, Toxicity, Vitellogenin, Hepatocyte, Marine Fish

\section{Introduction}

Aluminum $(\mathrm{Al})$ is a nonessential biological element that is toxic to fish, interfering with ion regulation (Verbost et al., 1989; Booth et al., 1988) and respiratory function (KarlssonNorrgren et al., 1985; Wood et al., 1988) in the gills. Fish reproduction is also impaired by this metal (Haux et al., 1988; Rask et al., 1990). For example, the spawning of perch is delayed in acidic water with high Al levels (Rask et al., 1990). Such environments have been shown to impair oogenesis due to the poor accumulation of egg yolk in the perch Perca fluviatilis (Runn et al., 1977) and by reducing egg number in the pupfish Cyprinodon nevadensis (Lee and Gerking, 1980).

After absorption by fish, Al accumulates in the liver (Buergel and Soltero, 1983; Norrgren et al., 1991; Exley, 1996), where vitellogenin (VTG, a calcium-binding phosphlipoglyco-protein), an egg yolk precursor protein, is synthesized in mature females under estrogen (estradiol-17 $\beta, \mathrm{E}_{2}$ ) stimulation.
VTG is also used as a nutrient source for embryonic and larval development until the beginning of feeding.

In recent years, attention has been paid to the potential significant impacts of ocean acidification on many calcifying organisms, especially corals and other invertebrates that precipitate aragonite skeletons (Hoegh-Guldberg, 2009). In contrast, the range of impacts that ocean acidification may have on marine fish remains poorly understood. Acidic water, including high Al concentrations may damage the reproductive physiology of stationary fish in coastal zones near estuarine outflow. However, few studies have investigated the effects of $\mathrm{Al}$ on the reproductive physiological processes of marine fish species. We used immature rockfish, Sebastes schlegeli, as an experimental fish. This species is an excellent indicator of coastal environment pollution, as it is fairly stationary in coastal rocky areas. The present study examined the toxic
Open Access http://dx.doi.org/10.5657/FAS.2011.0355

This is an Open Access article distributed under the terms of the Creative Commons Attribution Non-Commercial License (http://creativecommons. org/licenses/by-nc/3.0/) which permits unrestricted non-commercial use, distribution, and reproduction in any medium, provided the original work is properly cited. pISSN: 2234-1749 eISSN: 2234-1757
Received 11 August 2011; Revised 24 October 2011; Accepted 10 November 2011

*Corresponding Author

E-mail: vngi1@nfrdi.go.kr 
effects of $\mathrm{Al}$ on the liver, which is closely related to reproductive physiology in marine fish. Changes in plasma VTG induced by $\mathrm{Al}$ administration were analyzed by electrophoresis. The concentrations of plasma alkaline-labile phosphorus (ALPP) and calcium (Ca) were also analyzed using a quantitative analysis of inorganic phosphorus (Drummond L and Maher, 1984) and the o-cresolphthalein-complexone method (Björsson and Haux, 1985), respectively. An eventual toxic effect of $\mathrm{Al}$ administration was also analyzed by measuring the concentrations of plasma glutamate pyruvate transaminase (GPT), which has previously been used as an indicator of toxic effects on the liver (Hwang and Kang, 2002; Hwang et al., 2007). The hepatosomatic index (HSI) was expressed as liver weight $\times 100$ /body weight (BW). The concentration of Al in the liver was analyzed using an inductively coupled plasmamass spectrometer (ICP-MS).

\section{Materials and Methods}

Immature Sebastes schlegeli, weighing about $50 \mathrm{~g}$, were obtained from the Institute of Fisheries Sciences, Pukyoung National University (Busan, Korea) and kept in indoor tanks with continuously running water with $33 \pm 0.5$ psu salinity and a constant temperature of $18^{\circ} \mathrm{C}$. The fish were not fed during experimental periods.

\section{$E_{2}$ and $A l$ injection}

Fish were intraperitoneally injected with $\mathrm{E}_{2}(5 \mathrm{mg} / \mathrm{kg} \mathrm{BW})$ in $70 \%$ ethanol and $\mathrm{Al}\left(\mathrm{AlCl}_{3} \cdot 6 \mathrm{H}_{2} 0\right.$, Wako $)(0.1,1,5$, and 10 $\mathrm{mg} / \mathrm{kg} \mathrm{BW}$ ) in distilled water twice at 3-day intervals, and blood samples were obtained from the fish $(n=7$ per experimental tank), as described below, 7 days after the last administration. Control fish received the $\mathrm{E}_{2}$ only.

\section{Blood sampling}

Fish were anesthetized with 2-phenoxyethanol and their blood was collected by injecting the tail of the fish and by draining the blood into heparinized capillary tubes. Plasma was separated by centrifugation $(350 \mathrm{~g}, 8 \mathrm{~min})$ and frozen at $-20^{\circ} \mathrm{C}$ until the analysis of VTG, ALPP, Ca, and GPT concentrations.

\section{Effect of Al on VTG synthesis}

Protein concentrations of the plasma were determined according to the method of Bradford (1976). Plasma proteins were also analyzed by $5-20 \%$ sodium dodecyl sulfate polyacrylamide gel electrophoresis (SDS-PAGE) according to the method of Laemmli (1970). After SDS-PAGE, the integrated optical density (IOD) of the VTG band was measured using a Bio Image System (Millipore, Bedford, MA, USA) and was expressed as a percentage of the IOD of the total proteins including VTG. Minor subunits of VTG were not considered VTG, because the subunits constituted only a fairly small part of VTG and overlapped with other proteins (Kwon et al., 1993).

Fish were administered with Al twice at 3-day intervals, and were sampled 7 days after the last administration. The dosage was the same as described above. Plasma was separated from the blood of the fish and analyzed for the main VTG band by SDS-PAGE.

\section{Effect of Al on ALPP and Ca concentrations}

ALPP was analyzed from a $0.01 \mathrm{ml}$ sample according to the method of Wallace and Jared (1968) and determined by colorimetric assay of the acidified phosphomolybdate complex using a commercially available kit (670-A; Sigma, St. Louis, MO, USA). This kit consists of the necessary reagents including a phosphorus reagent and calcium/phosphorus standard. The absorbance of the standards and samples were measured by an atomic absorption spectrophotometer (10-AU Fluoro meter; Turner Designs, Sunnyvale, CA, USA) at $340 \mathrm{~nm}$.

$\mathrm{Ca}$ concentration was examined using a $\mathrm{Ca}$ assay kit (Asan Pharm. Co., Ltd, Seoul, Korea) by the $o$-cresolphthalein-complexone method (Björsson and Haux, 1985). The absorbance of the standard solution and samples were measured by an atomic absorption spectrophotometer (10-AU Fluoro meter; Turner Designs) at $575 \mathrm{~nm}$.

\section{Effect of Al on GPT concentration}

GPT was examined using an assay kit (Asan Pharm. Co., Ltd) flowing the method of Reitman-Frankel (Racicot et al., 1975). This kit consists of the necessary reagents including standard solution, reaction solution, assay solution, and $4 \mathrm{~N}$ $\mathrm{NaOH}$ solution.

The assay was conducted according to the kit instruction. Briefly, $1 \mathrm{~mL}$ reaction solution was added to $0.2 \mathrm{~mL}$ plasma in Al-administrated rockfish and then $0.4 \mathrm{~N} \mathrm{NaOH}$ was added and mixed at room temperature for $10 \mathrm{~min}$. Distilled water was used as the blank. The standard solution of GPT and samples were measured by an atomic absorption spectrophotometer (10-AU Fluoro meter; Turner Designs) at $505 \mathrm{~nm}$.

\section{Effect of Al on HSI}

The body and liver weights of Al-administrated fish were examined, and HSI was expressed as liver weight $\times 100 / \mathrm{BW}$.

\section{Analysis of $\mathrm{Al}$ in liver}

Fish were administered with Al twice at 3-day intervals and were dissected in the laboratory 7 days after the last administration. Liver samples were stored in a deep-freezer at $-20^{\circ} \mathrm{C}$ 


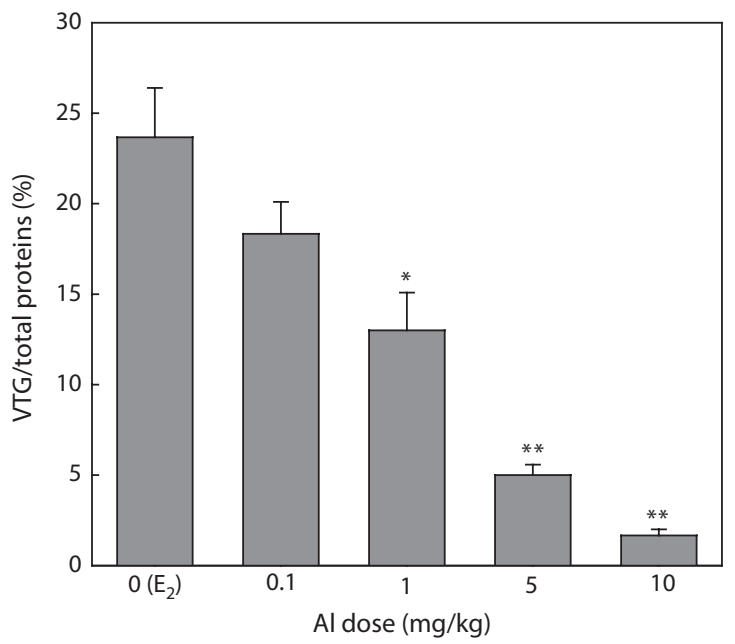

Fig 1. Concentration-dependent inhibition of vitellogenin (VTG) production in the plasma of aluminum (Al)-administered rockfish. The activity of VTG production was estimated as a percentage of VTG to total proteins after sodium dodecyl sulfate polyacrylamide gel electrophoresis on Day 7 after the Al last administration. Vertical bars represent the SE of the mean for the five individuals. ${ }^{*} P<0.05$ and ${ }^{* *} P<0.01$ for control $\left(E_{2}\right.$ only).

until analysis.

Liver samples were dried for $12 \mathrm{~h}$ at $80^{\circ} \mathrm{C}$ and $0.1 \mathrm{~g}$ dried tissue was digested with $1.5 \mathrm{ml}$ concentrated analytical $\mathrm{HNO}_{3}$ in a Teflon polytetrafluoroethylene tube in a microwave oven (Yasunaga et al., 2000; Anan et al., 2001). Al content was determined using an ICP-MS (HP-4500; Hewlett-Packard, Illinois, USA).

\section{Statistical analysis}

Data were analyzed by one-way analysis of variance (ANOVA) (Fisher protected least significant difference test). Fisher's tests were also used to examine the significance of correlation coefficients. Significance was accepted at $P<0.05$.

\section{Results and Discussion}

\section{Effect of Al on VTG synthesis}

Plasma samples were extracted and then analyzed by SDSPAGE in 7 days after $\mathrm{E}_{2}$ and/or Al administration. VTG accounted for $23.6 \%$ of the total proteins in the control group, but this value decreased with increasing $\mathrm{Al}$ dosage (Fig. 1). Significant inhibition was confirmed at Al dosages of 1, 5, and $10 \mathrm{mg} / \mathrm{kg}$, under which VTG productions were reduced to $54.2 \%(P<0.05), 20.8 \%(P<0.01)$, and $7.1 \%(P<0.01)$ of the control, respectively (Fig. 1).

Immature rockfishes were intraperitoneally administrated with Al to compare the eventual dosage-dependent response and to avoid large amounts of Al-polluted waste water during experiment periods. Enzyme linked immunosorbent assay is a sensitive method for VTG determination and has been widely used for this purpose. In the present study, however, SDS-PAGE was used to separate VTG before optical quantification. VTG production in the presence and absence of Al was expressed as a percentage of total proteins. This type of expression has the benefit of excluding the effects of variation in the amount of protein applied to the gel. It also has the advantage of checking the effects of $\mathrm{Al}$ on the production of proteins other than VTG. A significant decrease in percentage indicates that the synthesis of VTG is more susceptible to Al than are other hepatocyte-derived proteins.

$\mathrm{Al}$ is a nonessential biological element and therefore fish may have no regulatory mechanisms for it. The chemical form of $\mathrm{Al}$ depends on $\mathrm{pH}$. At neutral $\mathrm{pH}$, it occurs as $\mathrm{Al}(\mathrm{OH})_{3}$ precipitate and/or in a soluble $\mathrm{Al}(\mathrm{OH})_{4}^{-}$form (Verbost et al., 1992). As no precipitates were found, Al exerted its effect on vitellogenesis as an ion of $\mathrm{Al}(\mathrm{OH}) 4^{-} \mathrm{Al}$ is toxic to fish, interfering with ion regulation (Booth et al., 1988) and respiratory function (Wood et al., 1988) in the gills. Fish reproduction may also be impaired by this metal (Rask et al., 1990). Hwang et al. (2000) reported that $\mathrm{Al}$ inhibits VTG and its mRNA induction by $\mathrm{E}_{2}$ in the primary culture of hepatocytes in the rainbow trout Oncorhynchus mykiss. Nakao et al. (2002) reported that $\mathrm{Al}$ inhibits $\mathrm{E}_{2}$-induced VTG production in immature and male salmon Oncorhynchus masou. Similarly, in this study, Al inhibited $\mathrm{E}_{2}$-induced VTG production. These results suggest that the inhibitory action of $\mathrm{Al}$ on $\mathrm{E}_{2}$-induced VTG production in the rockfish Sebastes schlegeli is similar to that of previously studied freshwater fish species.

\section{Effect of Al on ALPP concentration}

Plasma samples were extracted and analyzed by colorimetric assay 7 days after $\mathrm{E}_{2}$ and/or $\mathrm{Al}$ administration. Plasma ALPP decreased in a concentration-dependent manner in all groups of Al-administered fish compared to the control group that had been treated with $\mathrm{E}_{2}$ only. Significant inhibition was confirmed at Al dosages of 5 and $10 \mathrm{mg} / \mathrm{kg}$, at which ALPP concentrations were reduced to $70.7 \%(P<0.05)$ and $66.2 \%(P$ $<0.05$ ) of the control, respectively (Fig. 2).

Emmersen et al. (1979) reported that plasma ALPP concentration increased in male flounder Platichthys flesus with $\mathrm{E}_{2}$ treatment in a way similar to that of VTG. Also, the increase in VTG synthesis by 4-nonylphenol exposure is similar to that of ALPP concentration, which has been shown to be a very reliable indicator of circulating VTG in fish (Nagler et al., 1987; Kramer et al., 1998). Similarly, the reduction in plasma ALPP concentration induced by $\mathrm{Al}$ administration was similar to that of VTG in this experiment using immature rockfish Sebastes schlegeli. 


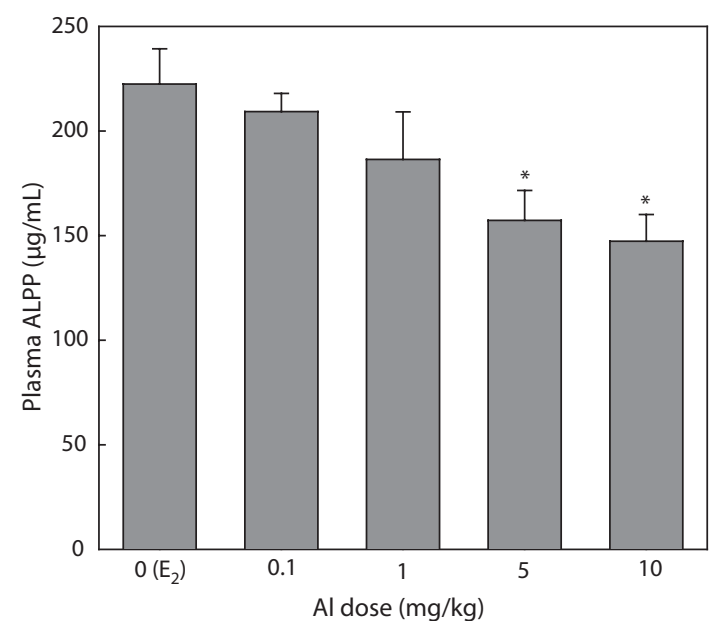

Fig. 2. Concentration-dependent inhibition of alkaline-labile phosphorus (ALPP) in the plasma of aluminum (Al)-administered rockfish. Vertical bars represent the $\mathrm{SE}$ of the mean for the five individuals. ${ }^{*} P<0.05$ for control ( $E_{2}$ only).

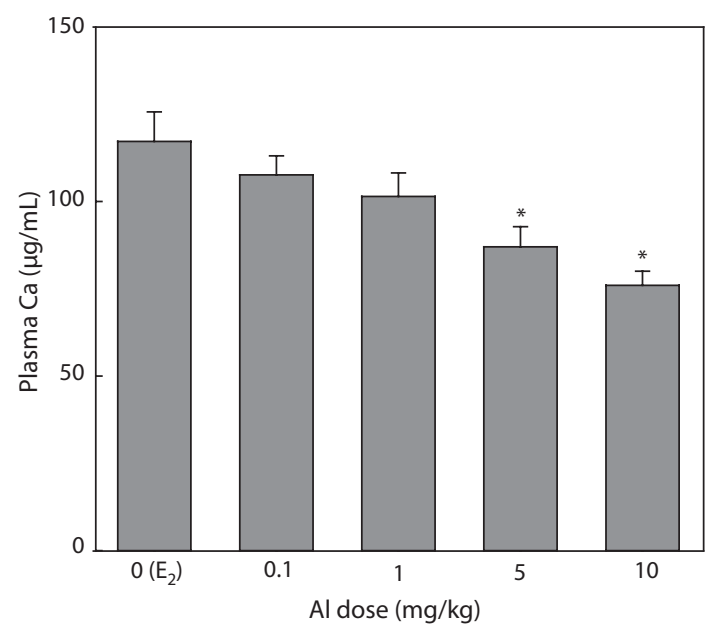

Fig. 3. Concentration-dependent inhibition of $\mathrm{Ca}$ in the plasma of aluminum (Al)-administered rockfish. Vertical bars represent the SE of the mean for the five individuals. ${ }^{*} P<0.05$ for control $\left(E_{2}\right.$ only).

\section{Effect of Al on Ca concentration}

Plasma samples were extracted and analyzed by the $o$ cresolphthalein-complexone method 7 days after $\mathrm{E}_{2}$ and/or $\mathrm{Al}$ administration. Plasma $\mathrm{Ca}$ also decreased in a concentrationdependent manner in all groups of Al-administered fish compared to the control group treated with $\mathrm{E}_{2}$ only. Significant inhibition was confirmed at Al dosages of $5 \mathrm{and} 10 \mathrm{mg} / \mathrm{kg}$, at which $\mathrm{Ca}$ concentrations were reduced to $74.7 \%(P<0.05)$ and $70.0 \%(P<0.05)$ of the control, respectively (Fig. 3$)$.

Nagler et al. (1987) and Tinsley (1985) reported that the concentration of plasma $\mathrm{Ca}$ can also indicate circulating VTG.

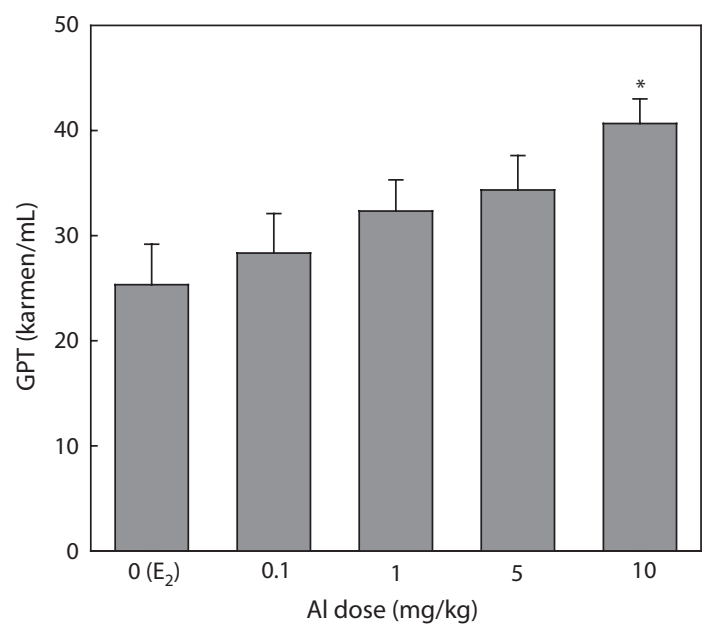

Fig. 4. Concentration-dependent increase of glutamate pyruvate transaminase (GPT) in the plasma of aluminum (Al)-administered rockfish. Vertical bars represent the $\mathrm{SE}$ of the mean for the five individuals. ${ }^{*} P<0.05$ for control ( $E_{2}$ only).

Ca binds to VTG, so that increased Ca may be mainly due to an increase in the protein-bound calcium fraction of the blood (Björsson and Haux, 1985). In the present study, the reductions in $\mathrm{Ca}$ concentration induced by $\mathrm{Al}$ administration were similar to those of VTG. In the flounder Platichthys flesus, total protein concentrations decrease with increasing dosages of 4-nonylphenol, because of the effect of 4-nonylphenol on hepatic tissue (Christensen et al., 1999). In this study, the concentrations of plasma $\mathrm{Ca}$ and total protein (data not shown) were reduced by $\mathrm{Al}$ administration.

\section{Effect of Al on GPT concentration}

Plasma samples were extracted and analyzed following the methods of Reitman-Frankel 7 days after $\mathrm{E}_{2}$ and/or $\mathrm{Al}$ administration. GPT increased in a concentration-dependent manner in all groups of Al-administered fish compared to the control group treated with $\mathrm{E}_{2}$ only. A significant increase was confirmed at an Al dosage of $10 \mathrm{mg} / \mathrm{kg}$, at which GPT was $25.3 \%$ higher than that of the control (Fig. 4).

The concentration of the plasma enzyme GPT has frequently been used to detect eventual damage to the liver cells. Hwang and Kang (2002) reported VTG induction by exogenous $\mathrm{E}_{2}$ damage to hepatocytes, and the concentration of plasma GPT was temporarily increased in immature Sebastes schlegeli. Also, a significant increase in GPT concentration was reported in immature rockfish administrated 4-nonylphenol (Hwang et al., 2007). In the present study, a significant increase was observed in the concentration of plasma GPT at $\mathrm{Al}$ dosages over $10 \mathrm{mg} / \mathrm{kg}$. This result indicates that Al damages the hepatic tissue. 


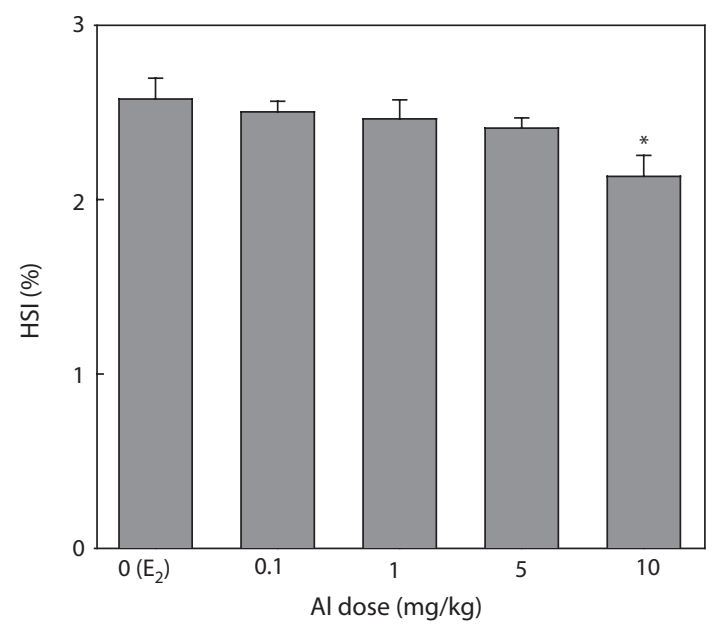

Fig. 5. The changes of hepatosomatic index (HSI) in Al-administered rockfish. Vertical bars represent the SE of the mean for the five individuals. " $P<0.05$ for control ( $E_{2}$ only).

\section{Effect of Al on HSI}

HSI was measured 7 days after $\mathrm{E}_{2}$ and/or $\mathrm{Al}$ administration (Fig. 5). HSI decreased in a concentration-dependent manner in all groups of Al-administered fish compared to the control group administered with $\mathrm{E}_{2}$ only. A significant reduction was confirmed at an Al dosage of $10 \mathrm{mg} / \mathrm{kg}$, at which HSI was reduced to $85.3 \%$ of the control (Fig. 5).

Emmersen et al. (1979) reported that HSI increases in fish with $\mathrm{E}_{2}$, because the fish liver is primarily hypertrophic for VTG synthesis. Hwang et al. (2007) also reported increases in HSI by 4-nonylphenol administration similar to those induced by $\mathrm{E}_{2}$. In the present study, $\mathrm{Al}$ inhibited $\mathrm{E}_{2}$-induced primary hypertrophy in the liver which reduced HSI.

\section{Al concentration in liver}

The concentrations of $\mathrm{Al}$ in the liver 7 days after $\mathrm{E}_{2}$ and/ or $\mathrm{Al}$ administration are shown in Fig. 6. Al concentration increased in a concentration-dependent manner in all groups of Al-administered fish compared to the control group treated with $\mathrm{E}_{2}$ only (Fig. 6). Significant increases were confirmed at Al dosages of 1,5 , and $10 \mathrm{mg} / \mathrm{kg}$, at which Al concentrations were $1 \pm 0.29,3.46 \pm 0.91$, and $5.38 \pm 0.92 \mu \mathrm{g} / \mathrm{g}$ dry wt, respectively (Fig. 6).

The livers of vertebrates such as fishes are an important organs for storing metals and for detoxification by biotransformation (Brown et al., 1984; Olsson et al., 1989). Due to its higher exposure to metal concentration compared to other tissues, the liver can also be used for the bio-monitoring of coastal pollution (Von Landwust et al., 1996; Broeg et al., 1999).

In the present study, as Al levels increased, so did GPT levels, whereas a decreasing HSI indicated that Al affected

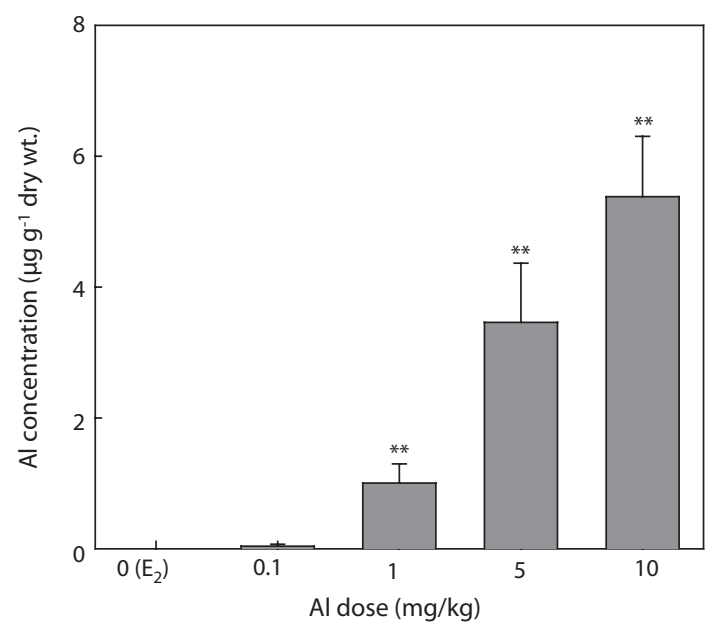

Fig. 6. Concentration-dependent increase of aluminum (Al) in the liver of Al-administered rockfish. Vertical bars represent the SE of the mean for the five individuals. ${ }^{*} P<0.05$ and ${ }^{* *} P<0.01$ for control ( $E_{2}$ only).

the physiological activity of the liver. The internal accumulation of metals in aquatic organisms such as fishes is attributed to the introduction of dissolved metals through their diet or through the gills as they breathe.

Although the results of this study are inconsistent with the natural absorption of metals, they are very helpful in that the eventual dose-dependent responses could be induced and large amounts of Al-polluted wastewater could be avoided during the experiments, as described above. The accumulation of heavy metal in the liver tissue of fishes depends on temperature, age, aquatic chemicals, exposure time, and the amount of exposure (Pagenkopf, 1983; Heath, 1987; Goyer, 1991). De la Torre et al. (2000) reported that as Cyprinus carpio was exposed to heavy metals, its plasmid GPT level showed a concentration-related response. In the present study, GPT and Al levels in the liver were also high in the experimental group, which was exposed to high concentrations.

In conclusion, our results suggest that the concentrations of plasma ALPP and Ca could be utilized as an index of reproductive physiology in fish, because the changes in these concentrations after $\mathrm{Al}$ administration were similar to those of VTG. GPT concentration and HSI changed temporarily as increasing Al accmulation damaged hepatocytes. These results indicate that $\mathrm{Al}$ affects $\mathrm{E}_{2}$-induced vitellogenesis in immature rockfish Sebastes schlegeli, which may result in the dysfunction of reproductive physiological processes by having toxic effects on hepatocytes.

\section{Acknowledgments}

This study was funded by a grant from the National Fisheries Research and Development Institute (NFRDI), Korea 


\section{References}

Anan Y, Kunito T, Watanabe I, Sakai H and Tanabe S. 2001. Treace element accumulation in hawksbill turtle (Eretmochelys imbricata) and green turtles (Chelonia mydas) from Yaeyama Islands, Japan. Environ Toxicol Chem 20, 2802-2814.

Björsson BT and Haux C. 1985. Distribution of calcium, magnesium and inorganic phosphate in plasma of estradiol-17 $\beta$ treated rainbow trout. J Comp Physiol B 155, 347-352.

Booth CE, McDonald DG, Simons BP and Wood CM. 1988. Effects of aluminium and low $\mathrm{pH}$ on net ion fluxes and ion balance in the brook trout, Salvelinus fontinalis. Can J Fish Aquat Sci 45, 15631574.

Bradford MM. 1976. A rapid and sensitive method for the quantitation of microgram quantities of protein utilizing the principle of proteins-dye binding. Anal. Biochem 72, 248-254.

Broeg K, Zander S, Diamant A, Körting W, Krüner G, Paperna I and Westernhagen HV. 1999. The use of fish metabolic, pathological and parasitological indices in polltion monitoring. I North Sea. Helgol Mar Res 53, 171-194.

Brown DA, Bay SM, Alfafara JF, Hershelman GP and Rosenthal KD. 1984. Detoxification/toxification of cadmium in scorpionfish (Scorpaena guttata) : acute exposure. Aquat Toxicol 5, 93-107.

Buergel PM and Soltero RA. 1983. The distribution and accumulation of aluminium in rainbow trout following a wholelake alum treatment. J Freshw Ecol 2, 37-44.

Christensen LJ, Korsgaard B and Bjerregaard P. 1999. The effect of 4-nonylphenol on the synthesis of vitellogenin in the flounder, Platichthys flesus. Aquat Toxicol 46, 211-219.

De la Torre FR, Salibián A and Ferrari L. 2000. Biomarkers assessment in juvenile Cyprinus carpio exposed to waterborne cadmium. Environ Pollut 109, 277-282.

Drummond L and Maher W. 1984. Determination of phosphate. In: A Manual of Chemical and Biological Methods for Seawater Analysis. Parsons TR, Maita Y and Lalli CM, eds. Pergamon Press, New York, US, pp. 22-25.

Emmersen J, Korsgaard B and Petersen I. 1979. Dosage-response kinetics of serum vitellogenin, liver DNA, RNA, protein and lipid after induction by estradiol-17 $\beta$ in male flounders (Platichthys flesus L.). Comp Biochem Physiol B 63, 1-6.

Exley C. 1996. Aluminium in the brain and heart of the rainbow trout. J Fish Biol 48, 706-713.

Goyer RA. 1991. Toxic effects of metals In: Casarett and Doull's Toxicology: The Basic Science of Poisons. 4th ed. Amdur MO, Doull $\mathrm{J}$ and Klaassen CD, eds. Pergamon Press, Oxford, GB, pp. 1033.

Haux C, Björnsson BTh, Förlin L, Larsson A and Deftos LJ. 1988. Influence of cadmium exposure on plasma calcium, vitellogenin and calcitonin in vitellogenic rainbow trout. Mar Environ Res 24, 199202.

Heath AG. 1987. Water Pollution and Fish Physiology. CRC Press, Boca Raton, FL, US.

Hoegh-Guldberg O. 2009. Climate change and coral reefs: Trojan horse or false prophecy? Coral Reefs 28, 569-575.

Hwang UG and Kang JC. 2002. Changes of plasma vitellogenin (VTG) and glutamate pyruvate transaminase (GPT) in the immature rockfish, Sebastes schlegeli exposed to exogenous estrogen. J Environ Toxicol 17, 239-243.

Hwang UG, Kagawa N and Mugiya Y. 2000. Aluminium and cadmium inhibit vitellogenin and its mRNA induction by estradiol-17 $\beta$ in the primary culture of hepatocytes in the rainbow trout (Oncorhynchus mykiss). Gen Comp Endocrinol 119, 69-76.

Hwang UK, An KH, Jin HK, Park SY, Kim PJ and Lee SM. 2007. Effects of 4-nonylphenol on the induction of plasma vitellogenin (VTG), alkaline-labile protein phosphorus (ALPP), calcium (Ca), glutamate pyruvate transaminase (GPT) and hepatosomatic index (HSI) in the immature rockfish, Sebastes schlegeli. J Environ Toxicol 22, 321-327.

Karlsson-Norrgren L, Runn P, Haux C and Förlin L. 1985. Cadmiuminduced changes in gill morphology of zebrafish, Brachydanio rerio (Hamilton-Buchanan), and rainbow trout, Salmo gairdneri. J Fish Biol 27, 81-95.

Kramer VJ, Miles-Richardson S, Pierens SL and Giesy JP. 1998. Reproductive impairment and induction of alkaline-labile phosphate, a biomarker of estrogen exposure, in fathead minnows (Pimephales promelas) exposed to waterborne 17 $\beta$-estradiol. Aquat Toxicol 40, 335-360.

Kwon HC, Hayashi S and Mugiya Y. 1993. Vitellogenin induction by estradiol-17 $\beta$ in primary hepatocyte culture in the rainbow trout, Oncorhynchus mykiss. Comp Biochem Physiol B 104, 381-386.

Laemmli UK. 1970. Cleavage of structural proteins during assembly of the head of bacteriophage T4. Nature 227, 680-685.

Lee RM and Gerking SD. 1980. Survival and reproductive performance of the desert pupfish, Cyprinodon n. nevadensis (Eigenmann and Eigenmann), in acid water. J Fish Biol 17, 507-515.

Nagler JJ, Ruby SM, Idler DR and So YP. 1987. Serum phosphoprotein phosphorous and calcium levels as reproductive indicators of vitellogenin in highly vitellogenin mature female and estradiol-injected immature rainbow trout (Salmo gairdneri). Can J Zool 65, 24212425.

Nakao W, Hwang UG, Tohse H and Mugiya Y. 2002. Aluminium inhibits protein kinase $\mathrm{C}$ activity in the liver without any effect on vitellogenin production in salmon (Oncorhynchus masou). Bull Fish Sci Hokkaido Univ 53, 31-36.

Norrgren L, Wicklund-Glynn A and Malmborg O. 1991. Accumulation and effects of aluminium in the minnow (Phoxinus phoxinus L.) at different $\mathrm{pH}$ levels. J Fish Biol 39, 833-847.

Olsson PE, Larsson A, Maage A, Haux C, Bonham K, Zafarullah M and Gedamu L. 1989. Induction of metallothionein synthesis in rainbow trout, Salmo gairdneri, during long-term exposure to waterborne cadmium. Fish Physiol Biochem 6, 221-229.

Pagenkopf GK. 1983. Gill surface interaction model for trace-metal toxicity to fishes: role of complexation, $\mathrm{pH}$, and water hardness. Environ Sci Technol 17, 342-347.

Racicot JG, Gaudet M and Leray C. 1975. Blood and liver enzymes in rainbow trout (Salmo gairdneri Rich.) with emphasis on their diagnostic use: study of $\mathrm{CCl}_{4}$, toxicity and a case of Aeromonas infection. J Fish Biol 7, 825-835.

Rask M, Vuorinen PJ and Vuorinen M. 1990. Delayed spawning of 
perch, Perca fluviatilis L., in acidified lakes. J Fish Biol 36, $317-$ 325 .

Runn P, Johansson N and Milbrink G. 1977. Some effects of low pH on the hatchability of eggs of perch, Perca fluviatilis L. Zoon 5, 115-125.

Tinsley D. 1985. A comparison of plasma levels of phosphoprotein, total protein and total calcium as indirect indices of exogenous vitellogenesis in the crucian carp Carrassius carrassius. Comp Biochem Physiol B 80, 913-916.

Verbost PM, Rooij JV, Flik G, Lock RAC and Wendelaar Bonga SE. 1989. The movement of cadmium through freswater trout branchial epithelium and its interference with calcium transport. J Exp Biol 145, 185-197.

Von Landwust C, Holst S, Moller H, Anders K, Momme M, Von Neuhoff N, Scharenberg W, Weis N, Lee K, Kohler-Gunther A,
Cameron P, Brauer F, Pluta JJ, Kruse R, Ballin U, Soffker K and Dethlefsen V. 1996. Fischkrankheiten in der Nordsee, Umweltbundesant Nr. 10603900 UBA Text 57/96. Umweltbundesamt, Berlin, DE.

Wallace RA and Jared DW. 1968. Studies on amphibian yolk. VII. Serum phosphoprotein synthesis by vitellogenic females and estrogen-treated males of Xenopus laevis. Can J Biochem 46, 953-959.

Wood CM, Playle RC, Simons BP, Goss GG and McDonald DG. 1988. Blood gases, acid-base status, ions, and hematology in adult brook trout (Salvelinus fontinalis) under acid/aluminum exposure. Can J Fish Aquat Sci 45, 1575-1586.

Yasunaga G, Watanabe I, Prudente MS, Subramanian A, Qui V and Tanabe S. 2000. Trace elements accumulation in waders from Asia. Toxicol Environ Chem 77, 75-92. 